\title{
Teachers' Assessment Literacy and Washback Effect of Assessment
}

\author{
Niveen R. M. Elshawa \\ Department of English, Faculty of Modern Languages and Communication, Universiti Putra Malaysia, 43400, Serdang, Selangor, Malaysia \\ E-mail: niveenshawa@yahoo.com \\ Chan Swee Heng \\ Department of English, Faculty of Modern Languages and Communication, Universiti Putra Malaysia, 43400, Serdang, Selangor, Malaysia \\ E-mail: shchan@upm.edu.my \\ Ain Nadzimah Abdullah (Corresponding author) \\ Department of English, Faculty of Modern Languages and Communication, Universiti Putra Malaysia, 43400, Serdang, Selangor, Malaysia \\ E-mail: ain@upm.edu.my \\ Sabariah Md. Rashid \\ Department of English, Faculty of Modern Languages and Communication, Universiti Putra Malaysia, 43400, Serdang, Selangor, Malaysia \\ E-mail:smrashid@upm.edu.my
}

Received: 06-02-2016

Published: 01-07-2016
Accepted: 03-05-2016

doi:10.7575/aiac.ijalel.v.5n.4p.135
Advance Access Published: May 2016

URL: http://dx.doi.org/10.7575/aiac.ijalel.v.5n.4p.135

\begin{abstract}
Assessment literacy, as a term, is not well known in the educational field. This is unfortunate because teachers' assessment knowledge and competence can have an important influence on the way they teach and the way their students learn. The relationship between the degree of assessment literacy a teacher has and the washback of this type of assessment is not clearly identified, especially in higher education context. In view of this gap, this article attempts to examine important assessment literacy issues in relation to student learning: definition and importance of assessment literacy, assessment in higher education and assessment practices through reviewing related studies. The review pinpoints the harmful effects of being assessment illiterate for both teachers and students.
\end{abstract}

Keywords: assessment, assessment literacy, student learning, washback

\section{Introduction}

Language testing plays a very important role in language teaching. It is a topic of concern to those involved in education, be they teachers, researchers or administrators. Language test, a means of testing or assessing a person's language ability, is a valuable tool for giving information regarding language teaching (Bachman and Palmer, 1996). In this regard, language testing provides goals for both language teaching and language learning. In other words, testing is inseparable from teaching and learning either in theory or in practice. In the classroom context, the term "washback" which refers to a test's influence on both learning and teaching has been given a considerable emphasis (Cain, 2005).

According to Alderson et al. (1996) cited in Arshad, (2004), washback is seen in the actions that teachers and students take which they would otherwise not do if there were no tests. Hence, a test can affect teaching and learning either in a positive or in a negative manner. If the effect is positive, then it is referred to as positive washback. In contrast, if it is negative, then the result is a negative washback (Arshad, 2004).

However, beneficial washback can also be achieved if the students and teachers are familiar with the test, its objectives as well as format. By being aware of the objectives of the tests, both students and teachers can prepare for it in an organized and a more directed manner (Hughes, 1989). Hughes also stresses the importance of assisting teachers as they prepare their students for tests. He maintains the argument that whenever a test is intended to create positive washback in teaching, it is likely that some teachers find it difficult to adapt their teaching techniques to the demands of the test. Hence, in such situations, it becomes imperative that these teachers are assisted in order for the test to have a positive washback effect. In other words, those teachers should have what is called 'assessment literacy' which can be defined as "the knowledge about how to assess what students know and can do, interpret the results of these assessments, and apply them to improve student learning" (Webb, 2002). This suggests that in order to improve students' learning (positive washback) a teacher needs to have assessment literacy. In other words, the level of assessment literacy that a teacher possesses can have a direct effect on students' course achievement and learning. For instance, a research has shown that teachers spend about twenty-five to thirty percent of their professional time preparing materials for assessing their students, almost without any background about the essentials of effective assessment (Stiggins, 2007). 


\section{Methodology of the Review}

To identify studies related to the topic of this review, an examination of the existing literature on assessment literacy and washback studies was conducted. This involved an extensive online search of databases, including EBSCO, SAGE Full-Text Collection, ProQuest, Google Scholar and Scopus.

First, keyword terms (looking across whole documents) were identified and searched to find studies related to assessment literacy and student learning. This resulted in a large number of finds which were directly or indirectly related to the current study. Thus, to get more specific results, the term 'assessment' alone was used to conduct the search. The term was then combined with washback, thus giving more search results. The search identified more than 300 documents. To reduce the number, studies directly related to two identified main themes were chosen: washback effects of high stake tests, and assessment literacy in the tertiary context.

\section{Common Themes of the Review}

Despite the widespread use of testing in preparing, guiding and evaluating students' learning, many teachers and test developers are still not familiar with the generally established ways of constructing tests (Gronlund, 1982). According to Gronlund, this may be explained by the fact that many teachers had received little or no training on how to prepare or construct tests. Hence, they have no idea about the various criteria to be included when designing a test such as validity and reliability. On the other hand, the situation may be also due to the test developers themselves ignoring the importance of test virtues including validity and reliability. Related to this, Alderson et al. (1996) state that their study in the field of testing revealed that among twelve UK tests reviewed, nine failed to provide sufficient evidence of reliability and validity.

\subsection{Washback Studies}

In spite of growing literature on washback, there are relatively little empirical studies in this area (Cheng, 2004). One can choose those which are directed towards exploring a specific aspect of washback. According to Pan (2008), these studies, in terms of their methods and results, made considerable contributions to different aspects of washback.

In the language classroom context, the research by Alderson and Wall (1993) is considered a pioneering 'washback' study. The nature of English language teaching classes in a wide range of contexts in Sri Lanka was investigated before and after the country adopted a new English examination in her education system. . The researchers suggested that to better understand the washback effects of tests, observation of language classrooms should be conducted to investigate teachers' attitudes towards these exams. In this manner, the issue of why teachers teach the way they do could be resolved.

In a study which examined the impact of national tests of Arabic as a Second Language and English as a Foreign Language, Shohamy et al. (1996) explored different washback patterns among teachers and students in terms of [mainly] time allotment, teaching materials, and classroom activities. The study's main conclusion was that washback was not stable due to several factors, among them were language status and test users had a vital role to play. However, this study had two limitations: first, it did not include observation as a tool; and second, the sample was too small to enable generalizations to be made (Pan, 2008).

To overcome these shortcomings, Alderson and Hamp-lyons (1996) conducted a study to investigate the influence of the Test of English as a Foreign Language (TOEFL) on classroom teaching. In this study, observations and interviews were used as data collecting methods. The conclusion was that TOEFL affects the content of the course as well as the method of teaching, but these effects were not the same among teachers. However, questionnaires were not used, thus bringing into question the issue of making generalization about the results of this study. Another limitation of the study is that it deals with washback from the teachers' point of view and nothing from the students' perspectives.

Later, in Cheng's (1999) study, classroom observations, questionnaires for teachers and students, and interviews were administered. This study was aimed at comparing teachers' perceptions towards the new and the old Hong Kong Certificate of Education Examination in English (HKCEE). The study concluded that change be made to what teachers teach rather than on how they teach. This was because the teachers being studied were found to not have adequate training and the necessary qualifications to teach at the secondary school level. Cheng's main contribution to washback studies was in using quantitative and qualitative methods.

In a similar vein, but in the context of international tests, IELTS writing test was the main concern of a study by Green (2007). It aimed at investigating the effect of test preparation classes in assisting students seeking to improve their IELTS scores in writing. The researcher's instruments of investigation were two questionnaires involving participant and process variables. The study revealed no apparent benefit from conducting test preparation classes to improve test scores.

As for Shih's study (2007), it was conducted to explore the effects of General English Proficiency Test (GEPT) exit requirements on learning in Taiwan. Interviews with teachers, students, departmental heads and family members as well as classroom observations were carried out to collect the data required. Since few studies of washback effects on students' learning processes are evident in literature, Shih's study made a significant contribution as it proved that current washback theory was not evident for GEPT. Hence, a new learning washback model was devised. A concluding remark made by Shih indicates the influence of test content on the way students learn. 
Altogether, the previous studies highlight the complexity of washback by showing how it takes place within both educational systems and social contexts. This complexity is evident in the interactions between the factors related to teaching/learning context and those beyond the classroom. Hence, it seems difficult to attribute impact to any one factor alone. This is in line with what was noted earlier by Messick (1996: 242): 'A poor test may be associated with positive effects and a good test with negative effects because of other things that are done or not done in the education system'. Given this complexity, a significant finding that can be derived from these studies is that, in order to get beneficial washback from the tests/examination, different types of problems need to be tackled at both the educational and societal levels.

However, in the tertiary education context, Wang's (2011) study provides a better understanding of the washback effect of tests on teaching. This study was conducted mainly to investigate the effect of a new educational reform that was carried out in the College English curriculum and the College English Test (CET) on the teachers' pedagogical strategies. Wang found that the teachers resisted and had negative perceptions of this test. The researcher suggested reform changes in teachers' knowledge, beliefs and attitudes if their practices are to be changed. These require an enhancement in teachers' assessment training to help them develop a positive attitude towards their role in the education system.

In a recent study conducted in the Iranian context, Damankesh and Babaii (2015) adopted a think-aloud data collection method to better understand students' psychological processes, strategies, and actions while taking a test. The subjects of the study were 80 Iranian male high school students. The findings revealed that, while sitting for this examination, students likely employed some strategies that exerted a negative influence on their learning. This forced them towards utilizing a measurement-driven approach to learning. However, they also tended to use some strategies that foster mental and linguistic abilities.

To sum up, it is clear that students and their learning are at the heart of assessment. Recent studies have focused on direct washback of standardized testing on students and learning. This has implications on teachers' assessment framework (e.g., what and how they assess). The findings of these studies reflect the need for more investigations into washback on students and their learning paralleled with more focus on improving the assessment literacy of teachers who administer those tests or exams.

\subsection{Assessment in the Higher Education Institutions}

It is a fact that in higher education standardized testing is not commonly a part of the educational context. Hence, instructors do not face the negative washback that often comes as a result of this type of assessment (White, 2009). As for institutions of higher education, Brown (2004:19) stated that educators in those institutions should have familiarity with the 'five cardinal criteria' that are essential to evaluate and design several kinds of assessment. These fundamental concepts along with explanatory questions are: validity, practicality, reliability, authenticity and washback effect. The fifth point makes it clear that assessment literacy is a key factor in having positive effects on learning and teaching (positive washback).

\subsubsection{Assessment Literacy: Definition}

As stated earlier, the current literature is full of different definitions for assessment literacy concept. One comprehensive definition of this concept is from Webb (2002) who defines it as "the knowledge about how to assess what students know and can do, interpret the results of those assessments, and apply the results to improve student learning and program effectiveness". Hence, 'assessment literate' educators should possess a number of skills connected with the fundamental issues of profound assessment practices. These skills include: defining learning objectives that can be assessed, making use of the different available assessment methods, making inferences from analyzing students' work, providing constructive feedback to students and communicating the results of assessment effectively (Sadler, 1998).

\subsubsection{The Importance of Assessment Literacy}

It can be stated that despite the important role of classroom assessments in influencing their teaching and their students' learning, teachers generally leave assessment issues to be considered at a later time of the academic year. This suggests the prominent use of assessment to measure students' achievements - assessment of learning- rather than assessment to help students learn-assessment for learning.

In the context of tertiary education, however, studies conducted to investigate university instructors' assessment practices are limited compared with the studies of assessment practices of K-12 teachers. Cheng et al (2008) reported on a comparative study of three different ESL/EFL university contexts in Hong Kong, Canada and China. They explored six main features of ESL/EFL practices of assessment: assessment plan conducted by instructors for the courses they teach, the relative distribution of marks given for course work and tests in their instruction, the kinds of assessment that they applied, the objectives for using each assessment, the timing and the sources of each method used. A semi-structured interview guide was used to minimize differences among the interviewers at the different universities within the three contexts included in the study. In total, seventy four ESL/EFL university instructors from twenty three universities were involved in the study. The instructors were from seven universities in Canada, eight from Hong Kong, seven from Beijing and one from a university in Tianjin, China. The findings supported the proposition that teachers' classroom assessment is an important factor that influences their teaching and inevitably affects their students' learning. 
In the same vein, a study was conducted in the Iranian context by Kiomrs et al. (2011). In this study the effects of teachers' assessment literacy were isolated to see their influence in moderating the washback effects of summative tests in the Iranian EFL context. A test of assessment literacy as well as a questionnaire on English language teaching practices were administered to 53 EFL secondary school teachers. The findings reported poor assessment knowledge by those teachers. However, this did not affect the ability of the teachers to teach for external tests. Nonetheless, assessment literate EFL teachers were found to be more likely to include non-washback practices in their English class room.

In the same Iranian context, a recent study conducted by Jannati (2015) investigated assessment-related perceptions and practices of Iranian ELT teachers. Eighteen EFL instructors from different English language institutes were interviewed to check their familiarity with the basic concepts and terminologies of assessment. Surprisingly, the findings showed that teaching experience had no significant effect on the way teachers perceived assessment. Moreover, it was found that their level of assessment literacy was not reflected in their practices, that is, their view of the vitality of reliability, validity, fairness and authenticity to assessment was not translated into practice in their classrooms when assessing students.

However, to show the importance of assessment literacy, Havnes (2004) states that improving student learning requires a corresponding improvement in the assessment system. Although teachers often assume that their students' learning is directed by teaching, "in practice, assessment directs student learning, because it is the assessment system that defines what is worth learning" (Havnes, 2004:1). In his study, Havnes also tried to explore the impact of assessment on student learning. He focused on the way assessment influenced student learning and teaching practices, the educational program design and learning material production. Using an ethnographic case study for seven students during an entire semester and conducting several interviews throughout the academic term and after the test, the study revealed the intricate relation between assessment and examination procedures on one side and 'backwash' effect on the other. The test questions along with the structure of the final assessment influenced the students' learning. The assessment procedures implemented affected the teaching methodology and the way the students learnt. Moreover, these assessment arrangements provided students with a clue to identify what was important to study.

Previously, however, in his article entitled “Are assessors professional?” (Holroyd, 2000) concluded that improving the assessment procedures was inevitable if enhancing learning within higher education was required. He asserted that "assessment is at the core of the academic role of educator and on that role can be centered a reclaimed professionalism for academics"(p.43)

Earlier, however, some researchers found inadequacies in assessment practices and other difficulties encountered by instructors in higher education institutions. Hodgman (1997) noted some problematic aspects of assessment in the higher education context. First, the type of assessment is often to be expected by students. Second, no connection is found between what is given in class and assessment. Third, not all of the course content is covered. Another point is that, students usually find it difficult to understand what they are being assessed for. Finally, students are usually assessed at the end of the course without being given any feedback (White, 2009:11). Thus, for many students, an assessment is seen as a process rather than as an educational experience; it is a process of "guessing what the teacher wants" (McLaughlin \& Simpson, 2004).

\subsubsection{The Development of Assessment Theory and Practice in Higher Education}

During the last two decades, some important changes have been identified in the literature on how assessment has changed in higher education. Holroyd (2000) summarized the general patterns of change in seven key findings: a growing concern of how to enhance assessment's learning purposes instead of accountability and certification purposes; an increasing emphasis on formative aspects of assessment rather than end-of-course assessment; more focus on using criterion referenced-assessment and less focus on norm-referenced assessment; more focus on giving constructive feedback rather than marks, grades and summary labels; using multiple methods of assessment rather than depending on one main method - summative assessment; using self and peer assessment rather than depending on assessment by teaching staff alone; and, considering assessment as part of the teaching process rather than as an activity taking place at the end of teaching.

This, however, has implications on the students' perspective. In assessing learning in tertiary education in Australia, James et al. (2002) noted that students nowadays study more effectively when they know the course goals and the learning objectives. Another finding was that students value real assessment tasks which contain challenges and involving skills needed in everyday life. Moreover, students prefer to be given the opportunity to choose how and when to be assessed. Therefore, it can be anticipated that the awareness of this changing nature of assessment in higher education, and of students' expectations of the way in which they will be evaluated, are important factors for improving instructors' assessment literacy.

\subsection{Key Ideas Influencing Teachers' Views and Practices of Assessment}

Educators in higher education institutes should be familiar with the "five cardinal criteria", that can be used for designing and evaluating different types of assessments (Brown, 2004: 19). However, to be assessment literate one needs more than being familiar with these basic principles. White (2009) states that assessment literate teachers need to be aware of four other related and important concepts which are types of assessment, using assessment to improve learning, how assessment affects a student's approach to learning and the constructive alignment model of course design. 
Assessing students' performance is one of the most essential duties of teachers. Yet, many teachers report that they do not feel adequately prepared for this task. Teachers often believe that they need remediation or assistance in applying assessment concepts and techniques, as well as making assessment-related decisions (Mertler \& Campbell, 2005). Research has shown that teachers lack essential assessment skills while administrators have low levels of assessment literacy. This assessment illiteracy has an effect of giving false results to the students, thereby, preventing them from reaching their full potential (Stiggins, 2001).

In the classrooms, teachers/instructors use assessments mainly for three purposes: diagnostic, formative and summative. Diagnostic, or pre-assessments, usually come before instruction. Instructors use it to check their students' previous knowledge and skills. It tells the teachers how to plan the course in advance. In this case, no grades are given because of the diagnostic nature of the tests.

Summative assessment, on the other hand, summarizes what students learned at the end of a course. Good examples of summative assessments are final exams, essays and performances. Grades or scores are given. Unfortunately, summative assessments or assessment of learning is widespread and is still used in secondary education and at a number of higher education institutions. Studies have shown that this type of assessment, when used alone, is not enough to enhance student learning. This is simply because waiting until the end of a course to figure out how well students have learned is too late to help them improve the way they learn (McTighe \& O'Connor, 2005).

The third type is formative assessment. This occurs alongside instruction and serves to provide feedback to teachers and students. It serves the purpose of guiding teachers and learners. Examples of this type of assessments are: nongraded quizzes, teacher observation, oral questioning and essay drafting in addition to self-and peer-assessment (White, 2009). According to Black \& Wiliam, (1998), assessment for learning, results in effective teaching, as they should go in line with each other.

\subsubsection{Assessment for Learning}

In a review of formative assessment literature, Black and Wiliam (1998) concluded that, in order to improve learning through assessment, several key factors should be considered: first, providing students with effective feedback; second, involving the students in learning process; third, taking account of the results of assessment; fourth, identifying the significant influence of assessment on students' motivation and self-esteem; and finally, involving the students in assessing themselves and thus helping them to improve. This, inevitably, can be considered as a recommendation to everyone involved in the field of teaching and learning. It calls for the reconsideration of the idea that dominates most educational institutions i.e., "assessment for measurement". A focus on 'assessment for learning ' should be used instead.

A central finding that supports this view was identified in a study conducted by Rust (2002). In the context of the national trend towards student-centered approach, this study sheds light on the research literature that investigates the impact of assessment on students' learning. It provides practical recommendations to help in developing suitable assessment strategies and learner-centered assessment practices which meet the Quality Assurance Agency (QAA) general principles on assessment. A major finding of this study was the claim that when choosing between a surface or deep approach to their learning, most students are found to be greatly influenced by the assessment strategies a teacher uses in class.

It can be concluded, as research on assessment shows, assessments have a direct washback effect on learning. Hence, if assessment merely rewards recall, students will be more prone to rote learning and memorizing facts. Similarly, if assessments focus on the understanding of principles, then deeper approaches to learning can be prompted. This reflects the fact that changes to assessment practice often have more influence on students' study pattern than teachers' methods of teaching and the curriculum itself (White, 2009).

\section{Prominent Course Design for Assessment: Constructive Alignment Model}

In his book, Teaching for Quality Learning at University (1999:11) educational psychologist John Biggs formulated the 'Constructive Alignment Model' in which he mentions that the essential principle of constructive alignment is that "a good teaching system aligns teaching method and assessment to the learning activities stated in the objectives". This means that different aspects of this framework must be in harmony to support effective learning. Biggs says that when the assessment framework is designed and applied in a proper way, it becomes an essential part of a course and helps to maximize and support student learning. Commenting on the practicality of this framework, White (2009) feels that it is challenging to be implemented.

\section{Implications and conclusion}

A review of important and prominent concepts related to assessment reveals that this area of academic literacy deserves more attention if the aim is to improve teachers' assessment practices and consequently, the students' learning approach.

Having assessment literate teachers can contribute to an increase in the incidences of positive washback of tests. This, however, cannot be achieved by traditional delivery methods of assessment courses that focus on theoretical issues of assessment. Rather, both in-service and pre-service teachers should be trained and become involved in practical cooperative workshops to improve their assessment practices. Moreover, making local, national and international testing and assessment journals accessible to those teachers can help improve their assessment literacy. Finally, 
modifying the structure of traditional, discrete-points final tests and using more classwork and ungraded tests as practice before the actual final tests are conducted, can help in getting positive washback and promoting teachers' assessment literacy.

Finally, it is important for professional educators who are interested in becoming more assessment literate to note that merely learning about the subjects they teach and improving their pedagogical skills, are no longer sufficient. Teachers have to identify their own assessment practices and to know how to use these practices to support and improve their students' learning.

\section{References}

Alderson, C., \& Hamp-Lyons, L. (1996). TOEFL Preparation Courses: A Study of Washback. Language Testing 13(3), 280-297.

Arshad Samad. (2004). Essentials of Language Testing for Malaysian Teachers. Malaysia, UPM Press.

Bachman, L. F., \& Palmer, A. (1996). Language Testing in Practice. Oxford: Oxford University Press.

Biggs, J. (1999). Teaching for quality learning at university. Buckingham: Oxford University Press.

Black, P., \& Wiliam, D. (1998). Inside the black box: Raising standards through classroom assessment. Phi Delta Kappan, 80(2), 139-148.

Brown, H. D. (2004). Language assessment: Principles and classroom practices. NY: Longman

Cain, N. (2005). EFL examination washback in Japan: Investigating the effects of oral assessment on teaching and learning. Master Dissertation. Retrieved from: http://www.asian-efl-journal.com/Thesis Washback_in_Japan_Caine.pdf

Cheng, L. (1999). Changing assessment: washback on teacher perceptions and actions. Teaching and Teacher Education, 15, 253-271.

Cheng, L. (2004). The washback effect of a public examination change on teacher's perceptions towards their classroom teaching. In L. Cheng, Y. Watanabe, \& A. Curtis (Eds.), Washback in language testing: Research contexts and methods. (pp.1147-1170). Malwah, New Jersey: Lawrence Erlbaum Associates.

Cheng, L., Rodgers, W., \& Wang, X. (2008). Assessment purposes and procedures in ESL/EFL classrooms. Assessment \& Evaluation in Higher Education, 33(1), 9-32.

Dahan, H. B. (2002). Language Testing: Construction and Validation. Malaysia, Kuala Lumpur: University of Malaysia Press.

Damankesh M., Babaii E. (2015). The washback effect of Iranian high school final examinations on students' test-taking and test-preparation strategies. Studies in Educational Evaluation, 45(1), 62-69. doi: http // 10.1016/j.stueduc.2015.03.009

Green, A. (2007). Washback to learning outcomes: a comparative study of IELTS preparation and university presessional language courses. Assessment in Education, 14 (1), 75-97.

Gronlund, N. E.(1982). Constructing Achievement Tests. (3 ${ }^{\text {rd }}$ ed.), New Jersey: Prentice-Hall.

Havnes. A. (2004). Examination and learning: An activity theoretical analysis of the relationship between assessment and educational practice. Assessment and Evaluation in Higher Education, 29 (2),159-176.

Hodgman, J. (1997). The development of self- and peer-assessment strategies for a design and project-based curriculum. Ulti BASE. Retrieved from http://ultibase.rmit.edu.au/ Articles/dec97/hodgm1.htm

Holroyd, C. (2000). Are assessors professional? Active Learning in Higher Education, 1(1), 28-44

Hughes, A. (1989). Testing for Language Teachers. Cambridge: CUP

Jannati, S. (2015) ELT Teachers' Language Assessment Literacy: Perceptions and Practices. IJRTE. Retrieved from: http://dergipark.ulakbim.gov.tr/ijrte/article/view/5000106872/0

James, R., McInnis, C., \& Devlin, M. (2002). Assessing learning in Australian universities. Centre for the Study of Higher Education, The University of Melbourne, Australia. From: http:/www.cshe.unimelb.edu.au/assessing learning/

Kiomrs, R., Abdolmehdi, R., \& Naser, R. (2011). On the interaction of test washback and teacher assessment literacy: The case of Iranian EFL secondary school teachers. English Language Teaching, 4(1). Retrieved from http://www.ccsenet.org/journal/index.php/elt/article/view/9677

McTighe, J., \& O’Connor, K. (2005). Seven practices for effective learning. Educational Leadership, 63(3), 10-17.

Messick, S. (1996).Validity and washback in language testing. Language Testing 13, 243-256.

Mertler, C. \& Campbell, C (2005) Teachers' Measuring and knowledge Application of Classroom Assessment Concepts: The Development of Assessment Literacy Inventory. Paper presented at the annual meeting of the American Educational Research Association, Montréal, Quebec, Canada. April 11-15, 2005

Pan, Y. (2008). A critical review of five language washback studies from 1995-2007: Methodological considerations. JALT Testing \& Evaluation SIG Newsletter. 12 (2), 2-16, Retrieved from: http://jalt.org/test/PDF/Pan1.pdf 
Rust, C. (2002). The impact of assessment on student learning. Active Learning in Higher Education, 3(2), $145-158$.

Sadler, D.R. (1998). Formative assessment: revisiting the territory. Assessment in Education, 5, 77-84.

Shih, C. (2007). A New Washback Model of Students' Learning. The Canadian Modern Language Review, 64 (1), $135-$ 162.

Stiggins, R. J. (2001). The unfulfilled promise of classroom assessment. Educational Measurement: Issues and Practice, 20(3), 5-15.

Stiggins, R. (2007). Conquering the formative assessment frontier. In J. McMillian (Ed.), Formative classroom assessment (pp.8-28).N Y: Colombia University Teachers College Press.

Wall, D., \& Alderson, J. C. (1993). Examining washback: the Sri Lankan impact study. Language Testing, 10(1), 41-69

Wang, J. (2011). A study of role of the 'teacher factor' in washback. Unpublished doctoral dissertation, University of McGill, Montreal.

Webb, N. (2002). Assessment literacy in Standards-based education setting. A paper presented at the annual meeting of the American Educational Research Association, New Orleans, Louisiana, April1-5.Retrieved from:http://www.wcer.wisc.edu/publications/workingpapers/Working_Paper_No_2002_4.pdf

White, E. (2009). Feature Article: Are You Assessment Literate? Some Fundamental Questions Regarding Effective Classroom-based Assessment. On CUE Journal, 3(1), 3-25. 